\title{
Buttressing of the Staple Line in Gastrointestinal Anastomoses: Overview of New Technology Designed to Reduce Perioperative Complications
}

\author{
L.S.F. Yo ${ }^{a}$ E.C.J. Consten ${ }^{a}$ H.M.E. Quarles van Ufford ${ }^{a}$ H.G. Gooszen ${ }^{b}$ \\ M. Gagner ${ }^{\mathrm{C}}$ \\ ${ }^{a}$ Meander Medisch Centrum, Amersfoort, and b Universitair Medisch Centrum, Utrecht, The Netherlands; \\ 'New York Presbyterian Hospital, New York, N.Y., USA
}

\section{Key Words}

Anastomosis · Staple line reinforcement $\cdot$ Bovine

pericardium $\cdot$ Laparoscopy

\begin{abstract}
Background: Mechanical stapling devices are widely used in all fields of surgery as they can cut and sew tissue in a quick and easy manner. However, complications like bleeding or leakage at the staple line are frequently encountered and can have devastating consequences. Recent developments have led to the introduction of staple line reinforcement to reduce these complications. Methods: The literature has been reviewed to find and describe different methods to improve stapled resections and to give an extensive overview of the different staple line reinforcement materials, their properties and indications. Results: Several types of staple line reinforcement are available. Reinforcement of the staple line with membranes of either non-, semi- or absorbable material seems to be effective in minimizing the risk of leakage and bleeding by providing strength to the cut tissue. Conclusion: Application of staple line reinforcement material seems a promising technique in preventing leakage and bleeding at the stapled suture line, thus potentially reducing complications of gastrointestinal surgery. More studies are needed to investigate the exact properties, behavior and effects of the staple line reinforcement material.
\end{abstract}

Copyright ๑ 2006 S. Karger AG, Basel

\section{KARGER}

Fax +4161306 1234 E-Mail karger@karger.ch www.karger.com (c) 2006 S. Karger AG, Basel

0253-4886/06/0236-0283\$23.50/0

Accessible online at:

www.karger.com/dsu

\section{Introduction}

In abdominal surgery, linear and circular cutting/stapling devices have been commonly used for many years. They allow for quick division and closure of tissue which shortens the operating time and are used for handling virtually all kinds of tissues [1]. For minimally invasive surgery, devices adapted to pass through the trocars are available. A wide array of staple devices from different companies are on the market. They vary in staple size, gap width and staple shape, each having its inherent drawbacks. Stapled resection and anastomosis have not shown fewer complications than hand-sewn procedures [2]. However, their use has become standard in many operations, because of the shortened operating time and reduced tissue manipulation.

Adjustments to the dimensions and mechanics of the devices have improved their functioning since the earliest types. However, complications still arise at the staple line when performing gastrointestinal resections. The type and frequency of complications depend on the performed resection and localization in the gastrointestinal tract. Additionally, a small part of the complications may be attributed to device failure [3].

A new approach to diminish complications is to use staple line reinforcement to buttress the staple line. In this paper, we attempt to illustrate this relatively new concept with its possible advantages and drawbacks.
Esther C.J. Consten

Meander Medisch Centrum, Department of Surgery

PO Box 1502

NL-3800 BM Amersfoort (The Netherlands)

Tel. +31 33850 2383, Fax +31 33850 7850, E-Mail E.Consten@meandermc.nl 
Complications of the staple line, such as anastomotic leakage and hemorrhage, are frequently encountered. Specific complications are related to different sites in the gastrointestinal tract (table 1).

Resection and anastomosis of the stomach have been in use for treatment of malignancy or ulcerative disease. While nowadays hardly employed for ulcerative disease, partial stomach resections are increasingly performed as a part of bariatric surgery. Complications related to the stapled resection or anastomosis usually consist of bleeding and, to a lesser extent, of leakage. Perioperative bleeding rates may vary from 6 to $15 \%[4,5]$. Anastomotic leaks are encountered in $1-5.5 \%$ of the cases [6], with accompanying complications such as severe sepsis.

Stapled colorectal anastomosis compared with handsewn anastomoses have not shown to have a better outcome [2]. Leak rates in colorectal anastomosis may vary from 7 to $13 \%$ and mortality following leak can range from 6 to $40 \%$ [2, 7]. Formation of abscess and fistula due to dehiscence are a dreaded complication after colorectal anastomosis and are hard to treat. Obstruction or stenosis is encountered in $6-10 \%$, but can usually be dilated with few clinical consequences [8].

Especially for colonic anastomosis, where leakage has the most devastating consequences, many attempts have been made to decrease the problem of anastomotic dehiscence by reinforcing the anastomosis and to facilitate construction.

\section{Efforts to Reduce Anastomotic Complications}

Technical aids for construction of anastomoses (table 2), such as the SBS tube and Coloshield, have not proven to be very successful. The SBS tube is a resorbable tube developed to give tissue support during construction for more adequate apposition and reduction of tension $[9,10]$. The Coloshield is a latex or silicone tube designed for physically barring the anastomosis from bacterial load, reduction of tension and protection against intraluminal content [11-13]. Decrease in leakage and dehiscence were reported; however, complications such as erosion of the tube through the bowel wall and obstruction were seen [14].

The application of fibrin glue to seal off the colonic anastomosis has been tested in an effort to reduce leakage of intraluminal content and strengthen the anastomosis. In rat models, it appeared not to be a feasible technique [15-17]. In gastric resection, the application of fibrin glue to support and seal off the staple line seemed more suc-
Table 1. List of complications at staple line

\begin{tabular}{llll}
\hline $\begin{array}{l}\text { Gastrointestinal } \\
\text { site }\end{array}$ & Complications & $\begin{array}{l}\text { Per- } \\
\text { centage }\end{array}$ & $\begin{array}{l}\text { Refer- } \\
\text { ences }\end{array}$ \\
\hline Colorectum & anastomotic dehiscence & $7-13$ & 2,7 \\
\hline Stomach & bleeding & $6-15$ & 4,5 \\
& anastomotic leakage & $1-4$ & 4,6 \\
\hline
\end{tabular}

Table 2. Aids for colorectal anastomosis construction

\begin{tabular}{lll}
\hline Device & Mechanism & Objective \\
\hline SBS tube & $\begin{array}{l}\text { nonattached intraluminal } \\
\text { degradable tube }\end{array}$ & $\begin{array}{l}\text { facilitating suturing, } \\
\text { temporary support }\end{array}$ \\
\hline Coloshield & $\begin{array}{l}\text { nondegradable intralu- } \\
\text { minal tube sewn to bowel }\end{array}$ & $\begin{array}{l}\text { shielding from } \\
\text { intestinal contents }\end{array}$ \\
\hline Fibrin glue & $\begin{array}{l}\text { glue application on the } \\
\text { outer side }\end{array}$ & $\begin{array}{l}\text { seal of seamline, sup- } \\
\text { porting anastomosis }\end{array}$ \\
\hline
\end{tabular}

cessful, which was shown both in a swine model and a clinical series [18].

The design of the stapler device itself has varied regarding staple shape, width and height. Also, the number of staple rows, two or three, may vary. Which one of these variations is employed is the choice of the manufacturer. To our knowledge, no comparative studies addressing these issues exist. However, all types of surgical stapler devices suffer from a certain amount of malfunctions contributing to postoperative complications. Brown and Woo [19] reported fatalities associated with surgical staplers based on Food and Drug Administration malfunction and injury reports. Failure of the staples to form was reported most frequently, but also device failures and misfirings were regularly observed. In $40.2 \%$, the device problems were followed by anastomotic failure. Nevertheless, it was noted that probably not all problems were reported. No relation with a specific brand of stapler device was determined.

\section{Staple Line Reinforcement}

Although considerably reducing operating time, stapled anastomosis has not been proven to be superior to hand-sewn anastomosis in terms of dehiscence, leakage and abscess formation $[2,20]$. 

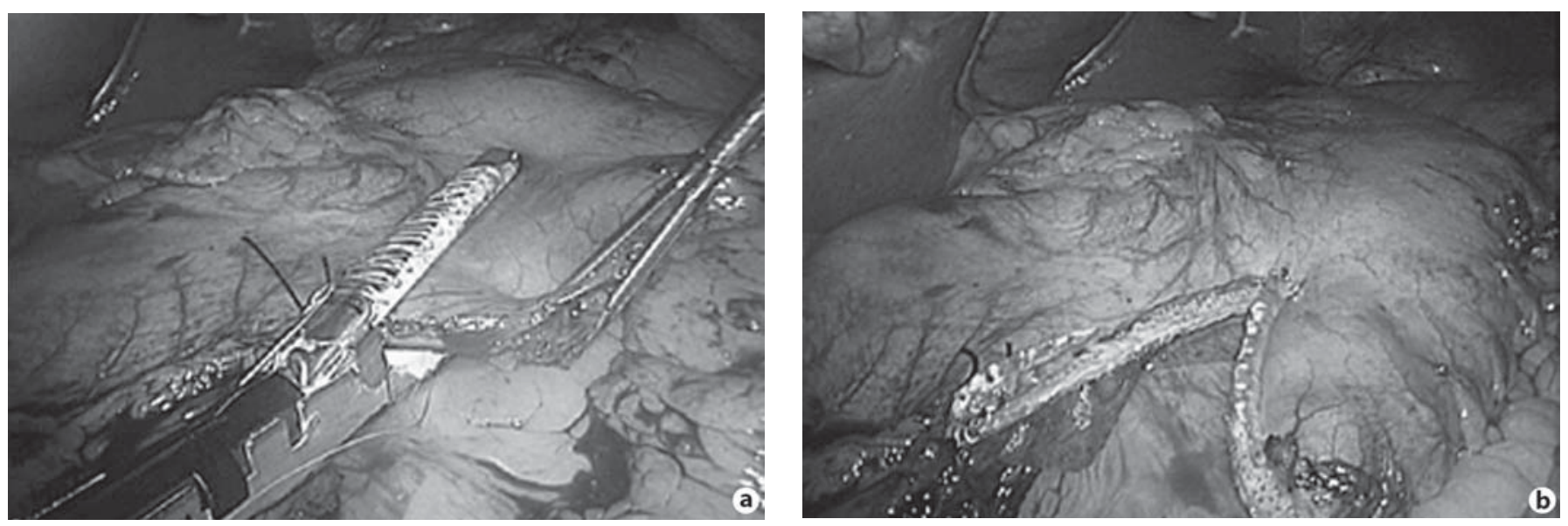

Fig. 1. Endoscopic stapler with staple line reinforcement material in laparoscopic Roux-en-Y gastric bypass before (a) and after stapling (b).

After resection and stapling, the integrity of the tissue will normally serve to prevent the staples from tearing through the tissue. When healing is completed, the staples either remain at the site of stapling or can be passed with the stools [21]. The staples do not elicit much cellular response. However, diseased tissue is often more fragile. Especially inflammatory processes reduce tissue strength due to decreased amounts of collagen [22-24]. Additionally, edema may form due to manipulation or disease. Decreased tissue strength combined with more manipulations will result in the staples tearing through the tissues, resulting in anastomotic leak or bleeding $[25,26]$.

During the operating procedure, bleeding at the staple line may hamper the visibility on the field of operation and prolong the operating time if extensive hemostasis is necessary. Especially in laparoscopic procedures, this can be an aggravating situation. As surgical staplers are used more frequently, it has become increasingly important to implement a reliable means to support fragile tissue to uphold the stapled line during the healing process and to provide a seal against bleeding and leakage.

A recent strategy employed to reduce and perhaps eliminate leaks and hemorrhage after gastrointestinal surgery is reinforcement of staples with various materials. A thin strip of buttressing material is incorporated between the staples and the tissue to ensure staple line security (fig. 1).

Application of reinforcement material in the staple line is thought to moderate tension of the staple line because it acts as a neutralization plate. Further, the but- tressing material seals off the staple holes and narrows the spaces in between each staple. Thus, leakage, bleeding and tearing at the staple line can be reduced, especially in diseased and fragile tissue.

Juettner et al. [27] described the addition of polydioxane ribbon to the staple line in severe emphysematous lungs, and Itoh et al. [28] did a similar study with absorbable poly (L-lactic acid-co-epsilon-caprolactone) film. The use of a bovine pericardial strip to reinforce the staple line in lung surgery was later reported in the mid nineties by Cooper [29]. Persistent air leaks and bleeding after pulmonary resection were controlled by using a strip of bovine pericardium to seal off the staple holes and the pulmonary margin. In several studies, staple line reinforcement was reported to have positive effects on air leak and bleeding [30-32]. Use of the bovine pericardium staple line reinforcement technique has since become frequent in pulmonary surgery $[31,33]$.

Following the beneficial results in lung resections, bovine pericardium staple line reinforcement was also used in gastric resections in an attempt to reduce complications. The two studies investigating this technique showed positive results regarding leakage and bleeding $[34,35]$ which were markedly reduced.

The success of the use of bovine pericardium staple line reinforcement has led to the development of different variants of the reinforcement concept. The goal of reinforcement of the staple line is different for the various organs. 
Table 3. List of different staple line reinforcement materials

\begin{tabular}{llll}
\hline & Material & Stapler type & Company \\
\hline Nonabsorbable material & ePTFE (Seamguard) & linear & $\begin{array}{l}\text { W.L. Gore \& } \\
\text { Associates, Inc. }\end{array}$ \\
\hline Semiabsorbable material & bovine pericardium (Peristrips Dry) & $\begin{array}{l}\text { circular } \\
\text { linear }\end{array}$ & $\begin{array}{l}\text { Synovis Life } \\
\text { Technologies, Inc. }\end{array}$ \\
\cline { 2 - 4 } & porcine small bowel (Surgisis) & linear & Cook Biotech Inc. \\
\hline Absorbable material & polyglycolic acid:trimethylene carbonate & linear & W.L. Gore \& \\
& (Seamguard bioabsorbable) & & Associates, Inc. \\
\cline { 2 - 4 } & cellulose (Xcell) & linear & Xylos Corp. \\
\hline
\end{tabular}

\section{Types of Reinforcement Materials}

Several types of staple line reinforcement materials are available. They can be categorized as nonabsorbable, semiabsorbable or bioabsorbable. Semiabsorbable materials of bovine origin and nonabsorbable expanded polytetrafluoroethylene (ePTFE) have been the earliest available materials. However, the use of bioabsorbable staple line reinforcement materials has also gained ground.

The bovine pericardium and ePTFE types were first indicated for lung resections, for which they are still predominantly used, and later for gastric resections. Currently, the range of indications is being expanded to resection of solid organs such as the pancreas, liver and spleen, and in the future, indication for colorectal resections is expected as well.

Here, we describe the different types of staple line reinforcement materials available (table 3 ).

\section{Nonabsorbable Material}

ePTFE, Seamguard Staple Line Reinforcement Materi$a l^{\circledR}$. This staple line reinforcement product is made of ePTFE (W.L. Gore \& Associates, Flagstaff, Ariz., USA). The material is constructed like a sleeve that can be slid over both arms of the stapling device, without need for additional fixing to the stapler before firing. After firing, the material is released from the arms by pulling a ripcord. If necessary, the excess material can be trimmed. This product is available for both open and endoscopic procedures $[36,37]$.

\section{Semiabsorbable Material}

Bovine Pericardium, Peristrips ${ }^{\circledR}$ Dry. The bovine pericardium strip, Peristrips Dry (Synovis Life Technologies, Inc., St. Paul, Minn., USA), is temporarily attached to the stapler with a gel. The gel is applied to the inner surface of both stapler arms after which the stapler is positioned over the bovine pericardium strips and locked. It takes approximately $2 \mathrm{~min}$ for the strips to adhere to the stapling device after which it is ready to be positioned and fired. With the bovine pericardium facing the tissue, the stapler device is fired and the tissue is cut after which the stapler can be removed. The remaining material will be incorporated by host tissue after healing.

The product has been indicated for resections of the stomach, the small bowel and the mesentery. Bovine pericardium staple line reinforcement material will be available for circular staplers in the near future.

Porcine Small Intestinal Submucosa, Surgisis ${ }^{\circledR}$ Staple Line Reinforcement. Staple line reinforcement manufactured of porcine small intestinal submucosa, Surgisis (Cook Biotech Inc., West Lafayette, Ind., USA), is another animal tissue buttress material suitable for anastomotic and nonanastomotic staplers. The material provides a bioscaffold for tissue growth. It is indicated for lung and gastric resections, but also for muscle flap reinforcement, repair of hernias and pelvic floor reconstructions [38, 39].

\section{Absorbable Material}

Polyglycolic Acid:Trimethylene Carbonate, Seamguard ${ }^{\circledR}$ Bioabsorbable Material. The Seamguard bioabsorbable staple line reinforcement (W.L. Gore \& Associates) (fig. 2) is made of a synthetic fiber web that is composed of polyglycolic acid:trimethylene carbonate Maxon polymer. This copolymer is found in many applications of which resorbable Maxon sutures are the most well known [40-42]. 


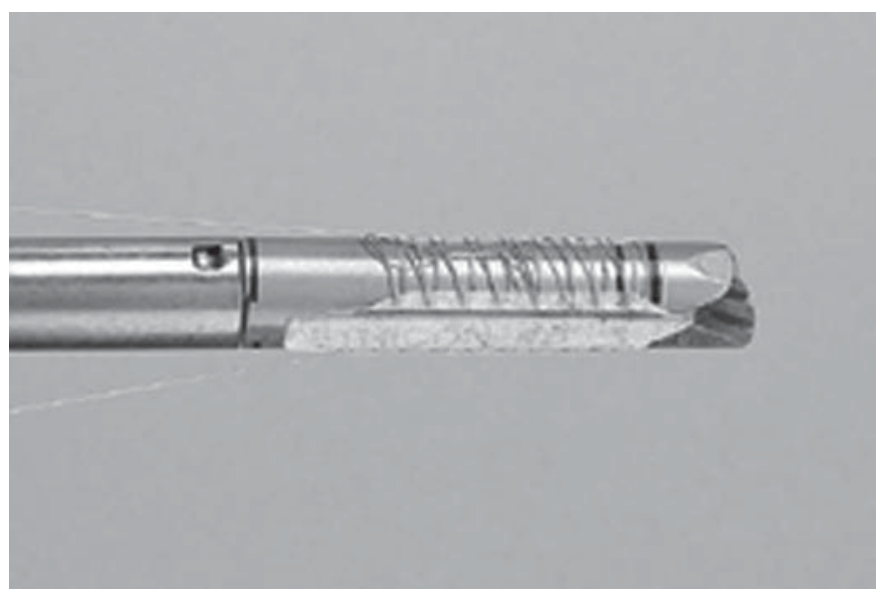

Fig. 2. Absorbable polymer membrane Seamguard (W.L. Gore \& Associates, Inc.) [46].

Like the ePTFE material, the Seamguard is formed like a sleeve to be fitted over the stapler arms and is released by pulling the suture that holds the sleeve in place.

Hydrolytic and enzymatic reactions lead to the breakdown of the material $[43,44]$ but invoke no antigenic response, which makes it strongly biocompatible. It maintains its strength for approximately 4-6 weeks, and after 6 months, the material is fully resorbed.

It has originally been indicated for soft tissue resections such as lung and gastric procedures, but recently, it has been approved for use in solid organs as well, such as the pancreas.

Cellulose, Xylos ${ }^{\mathrm{TM}}$ Surgical Reinforcing Material. Xcell SDMC surgical film (Xylos Corporation, Trenton, N.J., USA) is originally developed as a wound dressing. However, various medical applications are being developed from this biomaterial. This dry sterile material composed of microbially derived cellulose matrix has a multilayered, 3-dimensional structure [45]. The cellulose is produced by the Acetobacter xylinum bacteria. This biosynthesized cellulose has been processed into a resorbable form. Research is in progress to evaluate and construct it as a possible staple line reinforcing material used for gastrointestinal surgery.

\section{Properties of Ideal Reinforcing Material}

The outlined staple line reinforcement products are made of widely varying materials with different properties. To decide which would be the most ideal, it has been
Table 4. Important characteristics for staple line reinforcement material

Ease of use
Biocompatibility
Low infection potential
Flexibility and strength
Impermeability to fluids preventing leaks
Hemostatic properties
Low adhesion score

proposed that their properties should meet several demands as listed in table 4 [46].

A considerable difference exists between the various materials as far as these properties are concerned. For example, the ePTFE and Seamguard staple line reinforcement materials are very easily and quickly employed. Virtually no extra time is needed for the preparation and use of the material for both scrub nurse and surgeon. In contrast, bovine pericardium strips demand more handling time due to the required adherence to the stapler with a gel.

The presence of foreign material in the abdominal cavity should not lead to an increase in adhesions. No specific data are available for the different materials regarding this issue. However, Maxon polymer does not elicit an increase in adhesion formation when used for hand-sewn procedures in the abdominal cavity $[41,47]$. Therefore, in the form of staple line reinforcement material, it is expected not to increase adhesions either, although no mention has been made of it in the existing studies.

The absorbable materials have the advantage that they do not form a permanent foreign body. This may avoid dangers such as infection of the material. Xenomaterials such as the bovine pericardium strips additionally carry the risk of animal source contamination. More importantly, as it is integrated but not absorbed by the host tissue, there is a reasonable chance of migration of the material. Problems encountered with the use of nonabsorbable materials are described later.

\section{Experiences with Staple Line Reinforcement}

Bleeding at the staple line in partial stomach resections is rarely life-threatening, but it can be very aggravating especially during laparoscopic procedures. Impairment of visualization and excessive bleeding can be 
Table 5. List of studies supporting the efficacy of staple line reinforcement

\begin{tabular}{lrllll}
\hline Authors & Patients & GI site & Material & Benefit & $\begin{array}{l}\text { Level of } \\
\text { evidence }\end{array}$ \\
\hline Angrisani et al. [34] & 98 & stomach & bovine pericardium & yes & level I \\
Shikora et al. [35] & 250 & stomach & bovine pericardium & yes & level II \\
Consten et al. [4] & 20 & stomach & PGA:TMC & yes & level II \\
Nguyen et al. [50] & 34 & stomach & PGA:TMC & yes & level I \\
Franklin et al. [51] & 30 & colon & PGA:TMC & yes & level I \\
\hline
\end{tabular}

$\mathrm{GI}=$ Gastrointestinal $\mathrm{PGA}=$ polyglycolic acid; $\mathrm{TMC}=$ trimethylene carbonate. prevented with the use of staple line reinforcement, thus avoiding long and complicated procedures [48]. Additionally, tearing of tissue can be avoided by supporting the staple line with reinforcement material. This was shown in animal studies where burst pressure was significantly increased in reinforced staple lines [49].

In colorectal anastomosis, the postoperative dehiscence of the staple line is a prominent and life-threatening issue. The role of staple line reinforcement is to reduce tension by spreading forces evenly, to reduce the space in between staples and to prevent tearing of the staples through the tissue. In pulmonary resections, air leakage through the staple line was proven to be reduced. Thus, closure of the spaces between the staples in gastrointestinal resections may also be a means to reduce leakage of minute amounts of intraluminal content and bacteria to the abdominal cavity as well as malignant cells in case of tumor resection.

In addition to pulmonary resections, bovine pericardium staple line reinforcement has proven to be successful in bariatric procedures in several studies [34, 35]. During laparoscopic Roux-en-Y gastric bypasses, blood loss was significantly decreased or even absent, thereby improving the visibility with fewer conversions and reduced operating time. Postoperative leakage or staple line failure was diminished. These studies showed the effectiveness of the concept in the short term.

Though not much experience has been gained with absorbable material, evidence of its benefit is accumulating.

In two separate prospective studies, application of absorbable staple line reinforcement material (Seamguard) in gastric resections as part of bariatric surgery showed a significant reduction in blood loss $[4,50]$ and no leakage at intra- and postoperative testing.

The effects in colorectal anastomosis have been investigated in a pilot study of 30 patients in which all anasto- moses were performed with a linear stapler [51]. Although mainly safety and ease of use were demonstrated in this study, no bleeding and clinically apparent leakage could be seen at the staple line.

There is yet a limited number of level I studies to support the efficacy of staple line reinforcement (table 5). Currently, several trials are conducted for further investigation.

\section{Complications Related to Nonabsorbable Material}

Despite the positive results with staple line reinforcement, reports on complications also accumulated. Several cases have been published in which erosion and migration of the bovine pericardium into the lung was described after pulmonary resection causing pneumonia [52-56]. This complication was seen several weeks to months after resection. The same phenomenon of erosion and migration was seen in a patient after gastric resection. This patient was reported to expectorate fragments of the strip after 4 weeks [57] indicating that the material had migrated intraluminally. The intraluminal migration of the bovine pericardium may be due to an inflammatory reaction to the xenomaterial. No such cases have been described for ePTFE, which is observed to give less tissue response [37].

These problems with the bovine pericardium strip remaining in the operated area have led to the development of absorbable staple line reinforcement, which maintains the benefits, but avoids the complications due to the permanent and allogenic nature of the bovine pericardium $[58,59]$. No such undesirable side effects have been described for absorbable reinforcement material. 


\section{Discussion}

Resection and anastomosis of abdominal organs with stapler devices have become commonplace in surgical practice. Not only in open procedures are these devices frequently used, but with the rapid development of laparoscopic procedures, the use of endoscopic staplers has increased dramatically. Introduction of the endostapler has greatly facilitated laparoscopic procedures. Although the stapler devices in general shorten operating times, the number of complications has not been reduced. The introduction of staple line reinforcement may prove a solution to the problem of leakage, bleeding and dehiscence as the results so far have shown. However, choice of material is to be considered carefully. Although all types of staple line reinforcement seem equally adequate in reducing complications at the staple line, the material itself can cause problems. As described, bovine pericardium material is prone to erosion and migration due to inflammatory response and carries the risk of animal source contamination. Further, the demanding handling characteristics make it difficult to employ them quickly at the operating table. Erosion of the nonabsorbable ePTFE graft has never been reported. This may be due to the low host response to the material [37] as it is biocompatible, unlike bovine pericardium. Nevertheless, ePTFE will remain at the site of implantation even after its function is lost. The Seamguard offers a possible solution to this, being manufactured of biodegradable material: while the wound is healing it maintains its strength, but when the healing is complete, the material gradually dissolves. The polyglycolic acid:trimethylene carbonate (Maxon) polymer has a long history as absorbable suture. It is resorbed quickly and has no tendency to induce adhesions or other adverse events [41, 47]. Additionally, no risk of animal contamination exists and it is highly biocompatible.
Moreover, simple loading on the stapler ensures that it hardly takes any additional time to employ this type of staple line reinforcement.

The various studies suggest that there is a reduction in perioperative complications with the use of absorbable staple line reinforcement material. This may lead to a lower need for blood transfusion with a decrease in its associated risk. Fewer reoperations for postoperative bleeding or leakage may be expected as well, thus reducing the hospital stay. Increased recurrence of malignancy is seen after leakage of colorectal anastomosis, which has been attributed to spill of tumor cells through the anastomotic site [60-63]. If the incidence of leakage can be reduced as a result of staple line reinforcement, it seems likely that there would be a positive effect on tumor recurrence as well. All these aspects might lead to lower costs additional to the benefits for the patient.

Although the studies on the use of the various staple line reinforcement materials show a decrease in complications, it is not clear if any of them are superior, as no extensive comparative studies exist.

\section{Conclusion}

Staple line reinforcement technique is an effective technique in reducing perioperative complications in stapled resection and anastomosis. Different staple line reinforcement materials are available. In early experimental and clinical studies, absorbable staple line reinforcement material seems to have considerable advantages over non- or semiabsorbable staple line reinforcement. Not much experience has been gained with absorbable staple line reinforcement until now. However, as available results are very promising, this new technique needs further investigation.

\section{References}

1 McGuire J, Wright IC, Leverment JN: Surgical staplers: a review. J R Coll Surg Edinb 1997;42:1-9.

2 Lustosa SA, Matos D, Atallah AN, Castro AA: Stapled versus handsewn methods for colorectal anastomosis surgery. Cochrane Database Syst Rev 2001;CD003144.

3 Brown SL, Woo EK: Surgical stapler-associated fatalities and adverse events reported to the Food and Drug Administration. J Am Coll Surg 2004;199:374-381.
4 Consten EC, Gagner M, Pomp A, Inabnet WB: Decreased bleeding after laparoscopic sleeve gastrectomy with or without duodenal switch for morbid obesity using a stapled buttressed absorbable polymer membrane. Obes Surg 2004;14:1360-1366.

5 Mehran A, Szomstein S, Zundel N, Rosenthal R: Management of acute bleeding after laparoscopic Roux-en-Y gastric bypass. Obes Surg 2003;13:842-847.
6 Marshall JS, Srivastava A, Gupta SK, Rossi TR, DeBord JR: Roux-en-Y gastric bypass leak complications. Arch Surg 2003; 138: 520-523.

7 Chambers WM, Mortensen NJ: Postoperative leakage and abscess formation after colorectal surgery. Best Pract Res Clin Gastroenterol 2004;18:865-880.

8 Moran BJ: Stapling instruments for intestinal anastomosis in colorectal surgery. Br J Surg 1996;83:902-909. 
9 Sjolin KE, Skeie E, Naver L, Svendsen O, Jacobsen SD: New technique in anastomotic surgery - experimental and preliminary clinical experience. Zentralbl Chir 1994;119: 661-666.

-10 Buch N, Glad H, Svendsen P, Oxlund HR, Gottrup F, Hovendal CP: An intraluminal prosthesis may improve healing of a one-layer colonic anastomosis: an experimental study in pigs. Eur J Surg 2002;168:165-171.

-11 Ravo B, Reggio D, Frattaroli FM: Insertion of the Coloshield through a colotomy after completion of a colonic anastomosis. Int J Colorectal Dis 1991;6:46-48.

12 Ravo B: The Coloshield. Dis Colon Rectum 1988;31:579-580

13 Serra J, Capella G, Esquius J, Montanes R, Rius X: Experimental study of the efficacy of the endoluminal prosthesis in colonic anastomoses. Int J Colorectal Dis 1992;7:21-25.

14 Egozi L, Sorrento JJ, Golub R, Schultz EH: Complication of the intracolonic bypass. Report of a case. Dis Colon Rectum 1993;36: 191-193.

15 van der Ham AC, Kort WJ, Weijma IM, van den Ingh HF, Jeekel J: Effect of fibrin sealant on the healing colonic anastomosis in the rat. Br J Surg 1991;78:49-53.

-16 Kram HB, Clark SR, Ocampo HP, Yamaguchi MA, Shoemaker WC: Fibrin glue sealing of pancreatic injuries, resections, and anastomoses. Am J Surg 1991;161:479-481.

-17 Suc B, Msika S, Fingerhut A, Fourtanier G, Hay JM, Holmieres F, Sastre B, Fagniez PL: Temporary fibrin glue occlusion of the main pancreatic duct in the prevention of intraabdominal complications after pancreatic resection: prospective randomized trial. Ann Surg 2003;237:57-65.

-18 Nguyen NT, Nguyen CT, Stevens CM, Steward E, Paya M: The efficacy of fibrin sealant in prevention of anastomotic leak after laparoscopic gastric bypass. J Surg Res 2004;122: 218-224.

19 Brown SL, Woo EK: Surgical stapler-associated fatalities and adverse events reported to the Food and Drug Administration. J Am Coll Surg 2004;199:374-381.

-20 DochertyJG, McGregorJR, Akyol AM, Murray GD, Galloway DJ: Comparison of manually constructed and stapled anastomoses in colorectal surgery. West of Scotland and Highland Anastomosis Study Group. Ann Surg 1995;221:176-184.

-21 Kissin MW, Cox AG, Wilkins RA, Kark AE: The fate of the EEA stapled anastomosis: a clinico-radiological study of 38 patients. Ann R Coll Surg Engl 1985;67:20-22.

$\checkmark 22$ Hendriks T, Vereecken TH, Hesp WL, Schillings $\mathrm{PH}$, de Boer $\mathrm{HH}$ : Loss of collagen from experimental intestinal anastomoses: early events. Exp Mol Pathol 1985;42:411-418.

-23 Ahrendt GM, Gardner K, Barbul A: Loss of colonic structural collagen impairs healing during intra-abdominal sepsis. Arch Surg 1994;129:1179-1183.
24 Ahrendt GM, Tantry US, Barbul A: Intra-abdominal sepsis impairs colonic reparative collagen synthesis. Am J Surg 1996;171:102107.

25 Beart RW Jr, Kelly KA: Randomized prospective evaluation of the EEA stapler for colorectal anastomoses. Am J Surg 1981;141: 143-147.

26 Hogstrom H, Haglund U: Postoperative decrease in suture holding capacity in laparotomy wounds and anastomoses. Acta Chir Scand 1985;151:533-535.

27 Juettner FM, Kohek P, Pinter H, Klepp G, Friehs G: Reinforced staple line in severely emphysematous lungs. J Thorac Cardiovasc Surg 1989;97:362-363.

28 Itoh E, Matsuda S, Yamauchi K, Oka T, Iwata H, Yamaoka Y, Ikada Y: Synthetic absorbable film for prevention of air leaks after stapled pulmonary resection. J Biomed Mater Res 2000;53:640-645.

29 Cooper JD: Technique to reduce air leaks after resection of emphysematous lung. Ann Thorac Surg 1994;57:1038-1039.

30 Miller JI Jr, Landreneau RJ, Wright CE, Santucci TS, Sammons BH: A comparative study of buttressed versus nonbuttressed staple line in pulmonary resections. Ann Thorac Surg 2001;71:319-322.

-31 Hazelrigg SR, Boley TM, Naunheim KS, Magee MJ, Lawyer C, Henkle JQ, Keller CN: Effect of bovine pericardial strips on air leak after stapled pulmonary resection. Ann Thorac Surg 1997;63:1573-1575.

32 Stammberger U, Klepetko W, Stamatis G, Hamacher J, Schmid RA, Wisser W, Hillerjan L, Weder W: Buttressing the staple line in lung volume reduction surgery: a randomized three-center study. Ann Thorac Surg 2000;70:1820-1825

33 Vaughn CC, Wolner E, Dahan M, Grunenwald D, Vaughn CC III, Klepetko W, Filaire M, Vaughn PL, Baratz RA: Prevention of air leaks after pulmonary wedge resection. Ann Thorac Surg 1997;63:864-866.

34 Angrisani L, Lorenzo M, Borrelli V, Ciannella M, Bassi UA, Scarano P: The use of bovine pericardial strips on linear stapler to reduce extraluminal bleeding during laparoscopic gastric bypass: prospective randomized clinical trial. Obes Surg 2004;14:11981202 .

35 Shikora SA, Kim JJ, Tarnoff ME: Reinforcing gastric staple-lines with bovine pericardial strips may decrease the likelihood of gastric leak after laparoscopic Roux-en-Y gastric bypass. Obes Surg 2003;13:37-44.

36 Murray KD, Ho CH, Hsia JY, Little AG: The influence of pulmonary staple line reinforcement on air leaks. Chest 2002;122:21462149

37 Vaughn CC, Vaughn PL, Vaughn CC III, Sawyer P, Manning M, Anderson D, Roseman L, Herbst TJ: Tissue response to biomaterials used for staple-line reinforcement in lung resection: a comparison between expanded polytetrafluoroethylene and bovine pericardium. Eur J Cardiothorac Surg 1998; 13:259-265.

38 Kini S, Gagner M, de CJ, Gentileschi P, Dakin $\mathrm{G}$ : A biodegradeable membrane from porcine intestinal submucosa to reinforce the gastrojejunostomy in laparoscopic Rouxen-Y gastric bypass: preliminary report. Obes Surg 2001;11:469-473.

>39 de la Fuente SG, Gottfried MR, Lawson DC, Harris MB, Mantyh CR, Pappas TN: Evaluation of porcine-derived small intestine submucosa as a biodegradable graft for gastrointestinal healing. J Gastrointest Surg 2003; 7:96-101.

$>40$ Katz AR, Mukherjee DP, Kaganov AL, Gordon S: A new synthetic monofilament absorbable suture made from polytrimethylene carbonate. Surg Gynecol Obstet 1985;161: 213-222.

41 Metz SA, Chegini N, Masterson BJ: In vivo and in vitro degradation of monofilament absorbable sutures, PDS and Maxon. Biomaterials 1990;11:41-45.

42 Farrar DF, Gillson RK: Hydrolytic degradation of polyglyconate $\mathrm{B}$ : the relationship between degradation time, strength and molecular weight. Biomaterials 2002;23:39053912.

43 Van WW Jr, Hastings JC: Considerations in the choice of suture material for various tissues. Surg Gynecol Obstet 1972;135:113126.

44 Kangas J, Paasimaa S, Makela P, Leppilahti J, Tormala P, Waris T, Ashammakhi N: Comparison of strength properties of poly-L/Dlactide (PLDLA) 96/4 and polyglyconate (Maxon) sutures: in vitro, in the subcutis, and in the Achilles tendon of rabbits. J Biomed Mater Res 2001;58:121-126.

45 Frankel VH, Serafica GC, Damien CJ: Development and testing of a novel biosynthesized XCell for treating chronic wounds. Surg Technol Int 2004;12:27-33.

46 Consten EC, Gagner M: Staple-line reinforcement techniques with different buttressing materials used for laparoscopic gastrointestinal surgery: a new strategy to diminish perioperative complications. Surg Technol Int 2004;13:59-63.

47 Law WL, Bailey HR, Max E, Butts DR, Smith KW, Thompson DA, Skakun GB, Graves E: Single-layer continuous colon and rectal anastomosis using monofilament absorbable suture (Maxon): study of 500 cases. Dis Colon Rectum 1999;42:736-740.

48 Angrisani L, Borelli V, Lorenzo M, De Masi M, Canella M, Giuffre M: Extra-luminal bleeding during Roux-en-Y gastric bypass is reduced by using bovine pericardium strips (Peri-Strips Dry) on linear staplers. Obes Surg 2003;13:543.

49 Shikora SA: The use of staple-line reinforcement during laparoscopic gastric bypass. Obes Surg 2004;14:1313-1320.
Yo/Consten/Quarles van Ufford/ Gooszen/Gagner 
-50 Nguyen NT, Longoria M, Welbourne S, Sabio A, Wilson SE: Glycolide copolymer staple-line reinforcement reduces staple site bleeding during laparoscopic gastric bypass: a prospective randomized trial. Arch Surg 2005;140:773-778.

-51 Franklin ME Jr, Berghoff KE, Arellano PP, Trevino JM, Brego-Medina D: Safety and efficacy of the use of bioabsorbable seamguard in colorectal surgery at the Texas endosurgery institute. Surg Laparosc Endosc Percutan Tech 2005;15:9-13.

-52 Oey I, Waller DA: Metalloptysis: a late complication of lung volume reduction surgery. Ann Thorac Surg 2001;71:1694-1695.

53 Iwasaki A, Yoshinaga Y, Shirakusa T: Successful removal of bovine pericardium by bronchoscope after lung volume reduction surgery. Ann Thorac Surg 2004;78:21562157.

54 Provencher S, Deslauriers J: Late complication of bovine pericardium patches used for lung volume reduction surgery. Eur J Cardiothorac Surg 2003;23:1059-1061.
55 Shamji MF, Maziak DE, Shamji FM, Matzinger FR, Perkins DG: Surgical staple metalloptysis after apical bullectomy: a reaction to bovine pericardium? Ann Thorac Surg 2002;74:258-261.

56 Ahmed S, Marzouk KA, Bhuiya TA, Iqbal M, Rossoff LJ: Asymptomatic expectoration of surgical staples complicating lung volume reduction surgery. Chest 2001;119: 307-308.

57 Consten EC, Dakin GF, Gagner M: Intraluminal migration of bovine pericardial strips used to reinforce the gastric staple-line in laparoscopic bariatric surgery. Obes Surg 2004;14:549-554.

58 Kawamura M, Kase K, Sawafuji M, Watanabe M, Horinouchi H, Kobayashi K: Stapleline reinforcement with a new type of polyglycolic acid felt. Surg Laparosc Endosc Percutan Tech 2001;11:43-46.

59 Saito Y, Omiya H, Shomura Y, Minami K, Imamura $\mathrm{H}$ : A new bioabsorbable sleeve for staple-line reinforcement: report of a clinical experience. Surg Today 2002;32:297-299.
60 Walker KG, Bell SW, Rickard MJ, Mehanna D, Dent OF, Chapuis PH, Bokey EL: Anastomotic leakage is predictive of diminished survival after potentially curative resection for colorectal cancer. Ann Surg 2004;240: 255-259.

61 Petersen S, Freitag M, Hellmich G, Ludwig $\mathrm{K}$ : Anastomotic leakage: impact on local recurrence and survival in surgery of colorectal cancer. Int J Colorectal Dis 1998;13:160163.

62 Akyol AM, McGregor JR, Galloway DJ, Murray GD, George WD: Anastomotic leaks in colorectal cancer surgery: a risk factor for recurrence? Int J Colorectal Dis 1991;6:179183.

63 Chang SC, Lin JK, Yang SH, Jiang JK, Chen WC, Lin TC: Long-term outcome of anastomosis leakage after curative resection for mid and low rectal cancer. Hepatogastroenterology 2003;50:1898-1902. 